\title{
Karyotypic Heterogeneity in South American Annual Killifishes of the Genus Cynolebias (Pisces, Cyprinodontiformes Rivulidae)
}

\author{
G. García, E. Scvortzoff and A. Hernández \\ Instituto de Biologia, Sección Genética Evolutiva. Facultad de Ciencias, \\ Tristán Narvaja 1674. 11200 Montevideo. Uruguay
}

Accepted March 9, 1995

Explosive rate of morphological diversification is typical of members of the genus Cynolebias Steindachner, 1976. This endemic group of South American killifishes share with the African Rivulinae, Aphyosemion and Notobranchius, characteristic annual life cycles (Parenti 1981). Due to their rate of diversification they are appropiate organisms to examine mechanisms of chromosomal evolution and speciation.

Extensive intraspecific chromosomal variation and interspecific karyotypic divergence was found in natural populations of nine Cynolebias species from Uruguay and Argentine (Provincia de Entre Ríos) (Máspoli and García 1988, García et al. 1993). Diploid number varied from 34 to 48 chromosomes; with extensive variation in number of chromosome arms (NF) from 48 to 80 ; species with the same diploid number had different NF. Furthermore these observations led us to consider the ocurrence of alternating fusions and pericentric inversions proposed by Scheel (1972) for the evolution of karyotypes in other Rivulinae. The results from C-banding analysis and silver-stained NOR techniques were consistent with this hypothesis.

In this paper we describe for the first time, the karyotype, C-banding and $\mathrm{Ag}$-NORs of five species from West littoral, Atlantic littoral and Center of Uruguay and from Rio Grande Do Sul (Brazil) (Fig. 1). We also discuss the importance of chromosomal rearrangements in the speciation and cytotaxonomy of this group.

\section{Material and methods}

Live specimens were collected in temporary ponds. They belong to four species of Cynolebias from Uruguay and one species from Rio Grande Do Sul, Brazil (Fig. 1). Table 1 gives the detailed number, sex and localities of the 41 specimens analysed. The individuals were processed using conventional techniques for the study of fish chromosomes (Mc Phail and Jones 1966, Bertollo et al. 1978). Only somatic tissues (branchia, kidney and spleen) were studied.

Ten metaphases per individual were examined. Chromosomes were classified according to Levan et al. (1964) adopting the modifications by Denton (1973) for fish cytogenetics. They were grouped in two categories: biarmed $\mathrm{m}=(\mathrm{M}-\mathrm{SM})$ and uniarmed $\mathrm{a}=(\mathrm{ST}-\mathrm{A})$. When calculating the NF, evident small arms were considered.

The Nucleolar Organizer Regions (NORs) were identified by silver staining according to the technique of Howell and Black (1980) and constitutive heterochromatin was identified according to Sumner (1972) but modified for this material. 


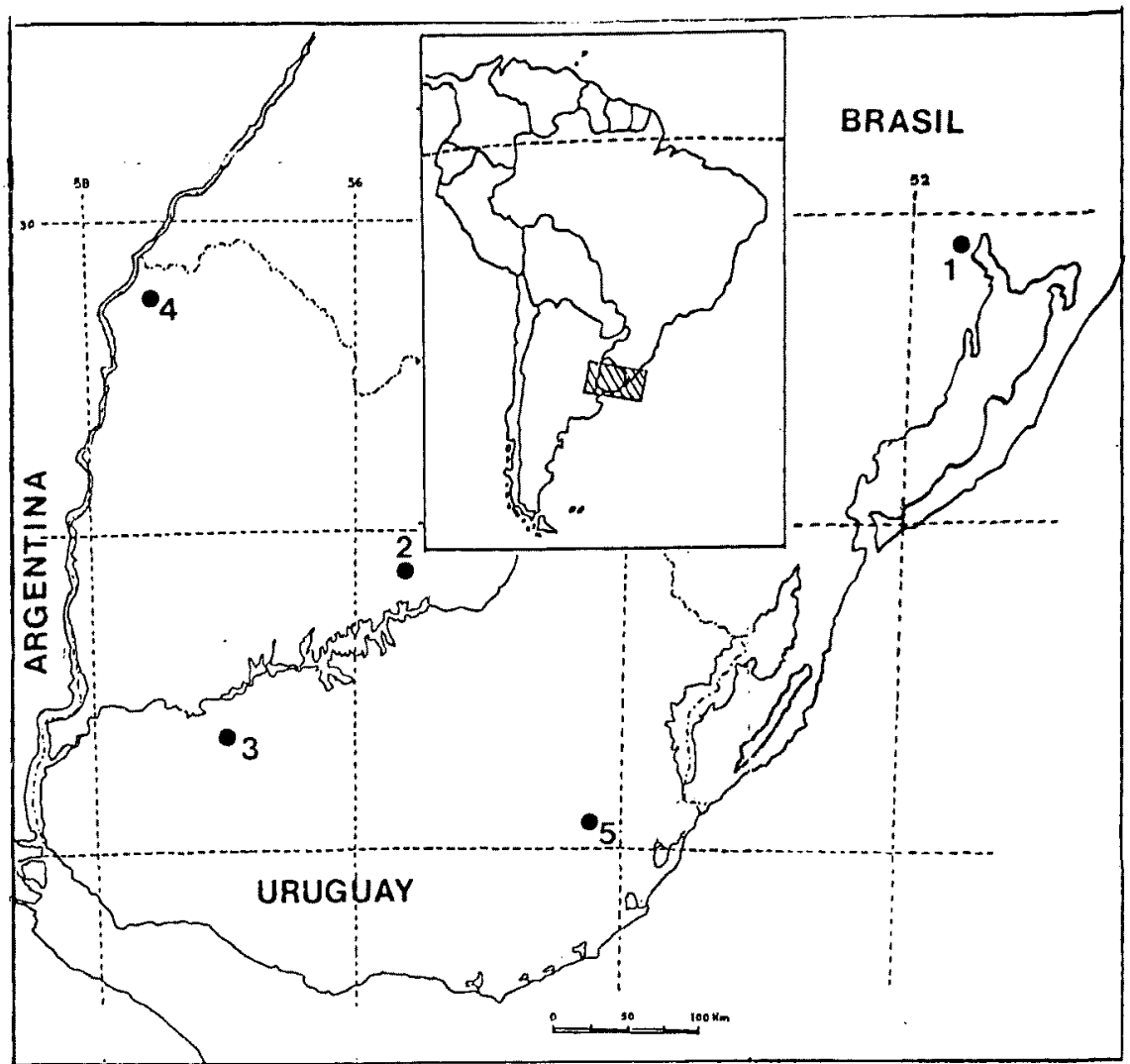

Fig. 1. Location of the 6 collection sites of the genus Cynolebias: 4 from Uruguay and 2 from Rio Grande Do Sul (Brazil). The species collected are: (1) C. adloffi, (2) C. affinis, (3) C. duraznensis, (4) C. alexandrii, (5) C. gymnoventris.

Table 1. Sex, number of specimens and localities

\begin{tabular}{llccc}
\hline \hline Species & \multicolumn{1}{c}{ Localities } & Males & Females & Total \\
\hline C. adloffi & R. 290km 82 (R. G. S.-BR.) & 1 & 3 & 4 \\
& P. Gravataí (R. G. S.-BR.) & 2 & 4 & 6 \\
C. affinis & A. Tres Cruces (Tacuarembó-UR.) & 0 & 2 & 2 \\
C. duraznensis & Durazno (UR.) & 5 & 5 & 10 \\
C. alexandrii & Salto (UR.) & 5 & 4 & 9 \\
C. gymnoventris & R. 13. Rocha (UR.) & 6 & 4 & 10 \\
\hline
\end{tabular}

R.G.S. $=$ Rio Grande Do Sul (Brazil), BR. $=$ Brazil, UR. $=$ Uruguay.

\section{Results}

\section{Chromosome numbers and $\mathrm{NF}$}

An important variation in the number of chromosome arms (NF), but not in chromosome number ( $2 n$ ), has been found among the five species of Cynolebias analysed in this work (Fig. 1a-e). Intrapopulation chromosome variation was also found in four of the five species analysed. The specific chromosomal constitution $(\mathrm{m}=\mathrm{M}-\mathrm{SM}, \mathrm{a}=\mathrm{ST}-\mathrm{A})$ are presented in Table 2. The presence of one or two biarmed chromosome pairs, the differential expression of acrocentric short arms and the presence of large acrocentric chromosomes were identified as chromosome markers that characterized each species. Also, the observation of large C-hetero- 

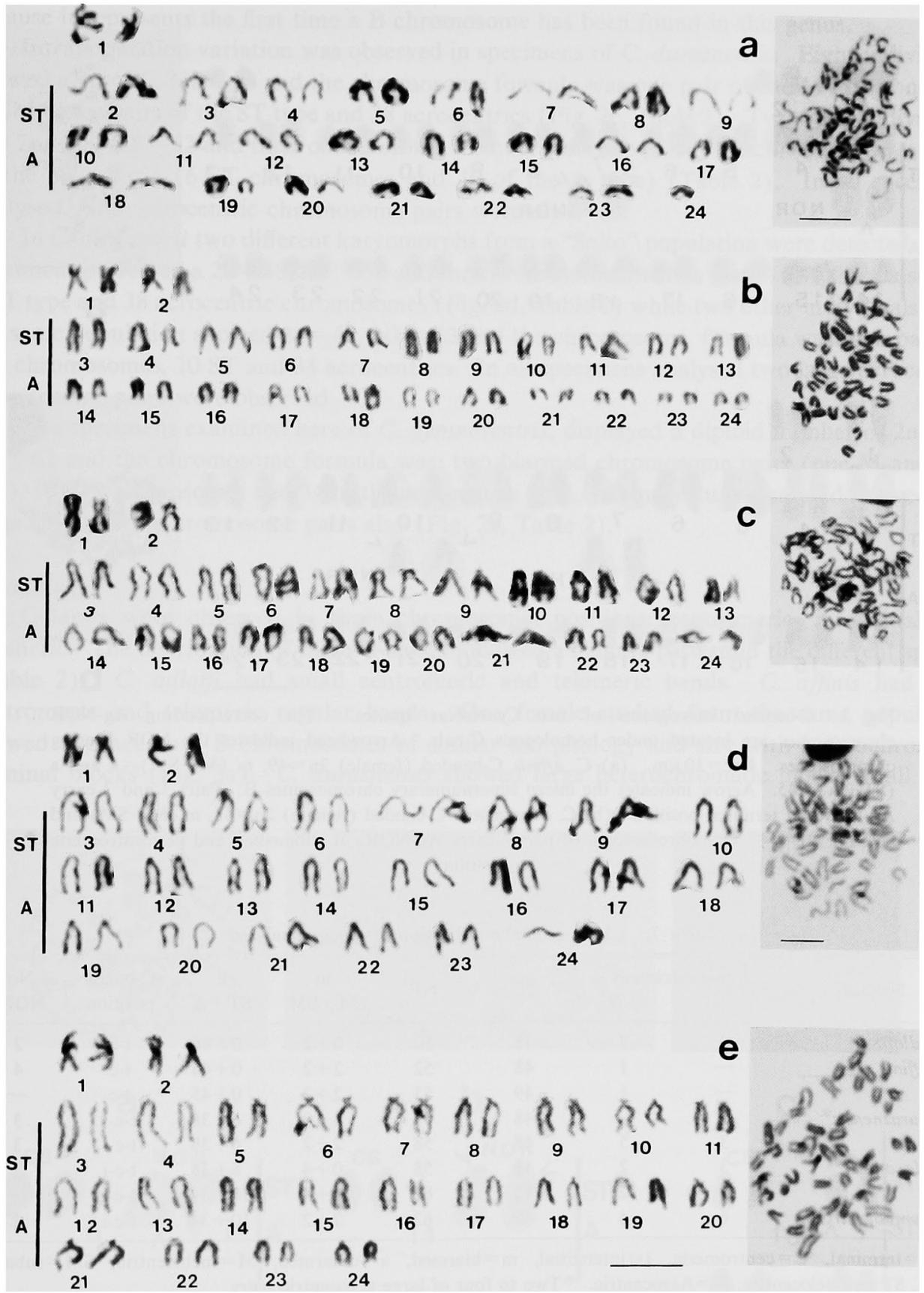

Fig. 2. Karyograms with Giemsa staining from somatic cells of five species of Cynolebias. $\mathrm{Bar}=10 \mu \mathrm{m}$. (a) C. adloffi (female) $2 \mathrm{n}=48, \mathrm{~m}(\mathrm{M}+\mathrm{SM})=2$ and a $(\mathrm{ST}+\mathrm{A})=46$. (b) $C$. affinis (female) $2 \mathrm{n}=48, \mathrm{~m}(\mathrm{M}+\mathrm{SM})=4$ and a $(\mathrm{ST}+\mathrm{A})=44$. (c) C. duraznensis (male) $2 \mathrm{n}=$ $48, \mathrm{~m}(\mathrm{M}+\mathrm{SM})=4$ and $\mathrm{a}(\mathrm{ST}+\mathrm{A})=44$. (d) $C$. alexandrii (male) $2 \mathrm{n}=48, \mathrm{~m}(\mathrm{M}+\mathrm{SM})=4$ and a $(\mathrm{ST}+\mathrm{A})=44$. (e) C. gymnoventris (male) $2 \mathrm{n}=48, \mathrm{~m}(\mathrm{M}+\mathrm{SM})=4$ and a $(\mathrm{ST}+\mathrm{A})=44$.

chromatic blocks, marks another characteristic.

All specimens studied of $C$. adloffi from two different localities of Rio Grande Do Sul (Brazil), presented a $2 n=48, N F=50$ and the chromosome formula was $1 \mathrm{SM}$ chromosome 


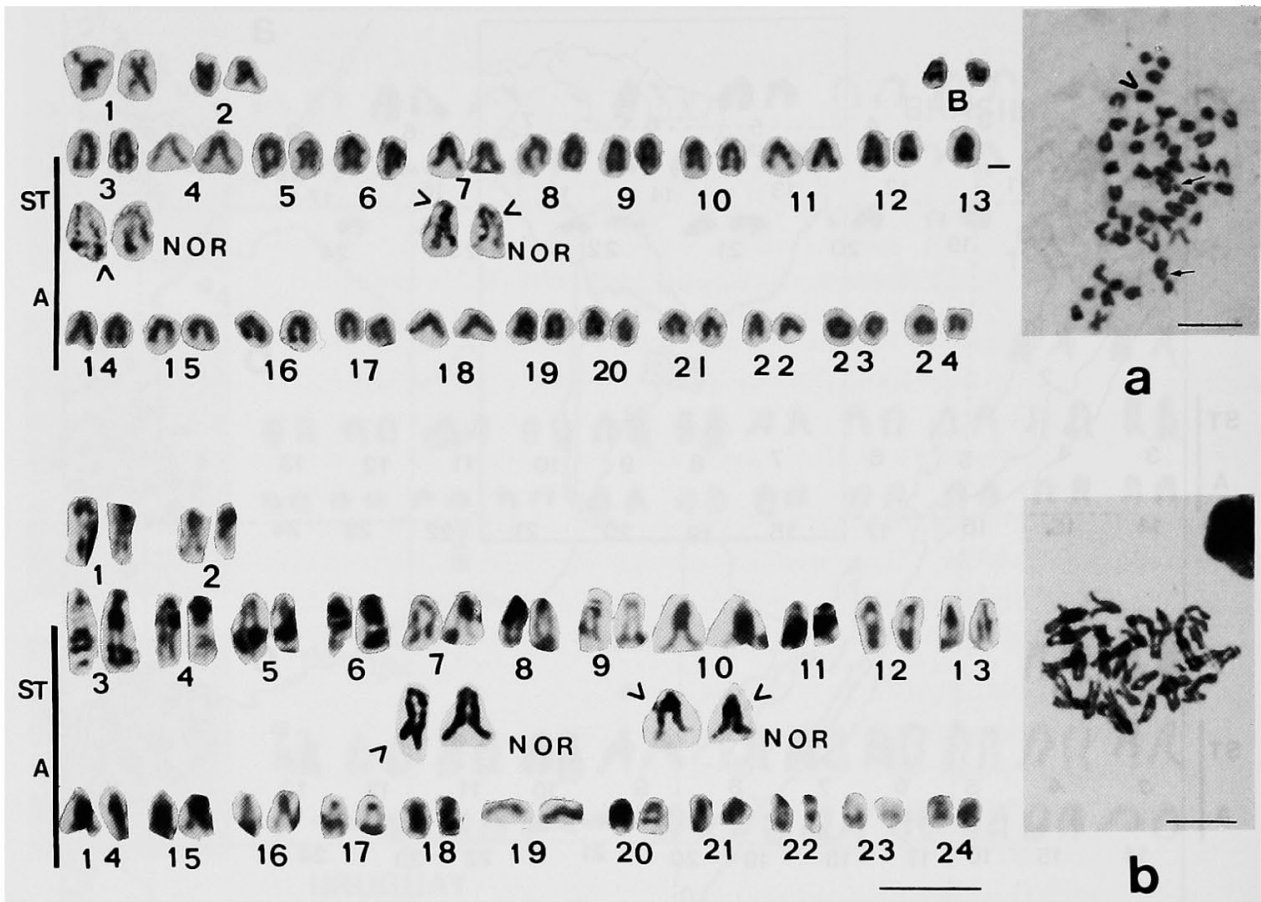

Fig. 3. C-banded karyograms of two Cynolebias species. The corresponding Ag-NOR chromosomes are located under homologous C-pair. Arrowhead indicates the NOR bearing chromosomes. Bar $=10 \mu \mathrm{m}$. (a) C. affinis C-banded (female) $2 \mathrm{n}=49, \mathrm{~m}(\mathrm{M}+\mathrm{SM})=4$ and a $(\mathrm{ST}+\mathrm{A})=45$. Arrow indicates the micro supernumerary chromosomes B. Pairs 3 and 7 carry Ag-NORs at terminal position. (b) $C$. duraznensis C-banded (female) $2 \mathrm{n}=48, \mathrm{~m}(\mathrm{M}+\mathrm{SM}$ ) and a $(S T+A)=44$. One chromosome of pair 7 carry Ag-NORs at submedian and pericentromeric position.

Table 2. Chromosomal constitution of species analysed

\begin{tabular}{|c|c|c|c|c|c|c|c|c|}
\hline \multirow{2}{*}{ Species } & \multicolumn{2}{|c|}{ No. specimens } & \multirow{2}{*}{$2 n$} & \multirow{2}{*}{ NF } & \multirow{2}{*}{$\underset{\mathbf{M}+\mathbf{S M}}{\mathbf{m}}$} & \multirow{2}{*}{$\stackrel{\mathrm{a}}{\mathrm{ST}}+\mathbf{A}$} & \multirow{2}{*}{$\begin{array}{l}\text { C-bands } \\
\text { position }\end{array}$} & \multirow{2}{*}{$\begin{array}{c}\text { No. } \\
\text { NORs }\end{array}$} \\
\hline & $\sigma^{\pi} \sigma^{\pi}$ & 우 우 & & & & & & \\
\hline C. adloffi & 3 & 7 & 48 & 50 & $0+2$ & $0+46$ & $t-c$ & 2 \\
\hline \multirow[t]{2}{*}{ C. affinis } & - & 1 & 48 & 52 & $2+2$ & $0+44$ & $t-c$ & 4 \\
\hline & - & 1 & 49 & 53 & $2+2$ & $0+45$ & $t-c$ & - \\
\hline \multirow[t]{2}{*}{ C. duraznensis* } & 2 & - & 48 & 52 & $4+0$ & $6+38$ & $t-c-i$ & 3 \\
\hline & 3 & 5 & 48 & 58 & $2+2$ & $6+38$ & $t-c-i$ & 3 \\
\hline \multirow[t]{2}{*}{ C. alexandrii* } & 3 & 2 & 48 & 58 & $0+4$ & $6+38$ & $t-c-i$ & 2 \\
\hline & 2 & 2 & 48 & 62 & $0+4$ & $10+34$ & $t-c-i$ & - \\
\hline C. gymnoventris* & 6 & 4 & 48 & 62 & $2+2$ & $10+34$ & $t-c-i$ & 2 \\
\hline
\end{tabular}

$\mathbf{T}=$ terminal, $\mathbf{C}=$ centromeric, $\mathrm{i}=$ interstitial, $\mathrm{m}=$ biarmed, $\mathrm{a}=$ uniarmed, $\mathbf{M}=$ metacentric, $\mathbf{S M}=$ submetacentric, $\mathbf{S T}=$ subtelocentric, $\mathrm{A}=$ Acrocentric. ${ }^{*} \mathrm{~T}$ wo to four of large acrocentric pairs.

pair and 46 acrocentric chromosomes (Fig. 2a, Table 2).

Two different karyomorphs were detected within a population of $C$. affinis. One specimen exhibited a $2 n=48, N F=52$ and the chromosome formula presented two pairs of biarmed chromosomes (one $\mathrm{M}$ and one SM chromosome pairs) and 44 acrocentric chromosomes (Fig. $2 b$, Table 2). The other female analysed had a $2 n=49, N F=53$ and its chromosome formula was: two pairs of biarmed chromosomes, 45 acrocentric chromosomes. Two micro supernumerary chromosomes (Fig. 3a) were also observed in this species. This finding is noteworthy 
because it represents the first time a $B$ chromosome has been found in this genus.

Intrapopulation variation was observed in specimens of $C$. duraznensis. Eight individuals showed a $2 n=48, N F=58$ and the chromosome formula was one pair of the $M$ type, one pair of SM, three pairs of the ST type and 38 acrocentrics (Fig. 2c, Table 2). Two other individuals had $2 n=48, N F=52$ and their chromosome formula was: one pair of $M$ chromosomes and 46 of the ST-A type (6 ST chromosomes and 40 of the A type) (Table 2). In all specimens analysed, large acrocentric chromosome pairs were observed.

In C. alexandrii two different karyomorphs from a "Salto" population were detected. Five specimens presented a $2 \mathrm{n}=48, \mathrm{NF}=58$ and the chromosome formula was: $4 \mathrm{SM}$ chromosomes, 6 ST type and 38 acrocentric chromosomes (Fig. 2d, Table 2) while two other individuals from the same population showed $2 n=48, N F=62$ and the chromosome formula was: two pairs of SM chromosomes, 10 ST and 34 acrocentrics. In all specimens analysed two large acrocentric chromosome pairs were observed.

The specimens examined here of $C$. gymnoventris, displayed a diploid number of $2 n=48$, $\mathrm{NF}=62$ and the chromosome formula was: two biarmed chromosome pairs (one $M$ and one SM), 10 ST chromosomes and 34 of the acrocentric type. All individuals analysed showed two large acrocentric chromosome pairs also (Fig. 2e, Table 2).

\section{C-banding}

C-bands were observed in three chromosomal positions: centromeric, interstitial and telomeric. The distribution of these C-bands followed a definite pattern in the different species (Table 2). C. adloffi had small centromeric and telomeric bands. C. affinis had both centromeric and telomeric regular bands. One female studied from the same population showed two accesory $B$ chromosomes of similar morphology and size with heterochromatic terminal blocks (Fig. 3a). C. duraznensis showed large heterochromatic blocks in all three

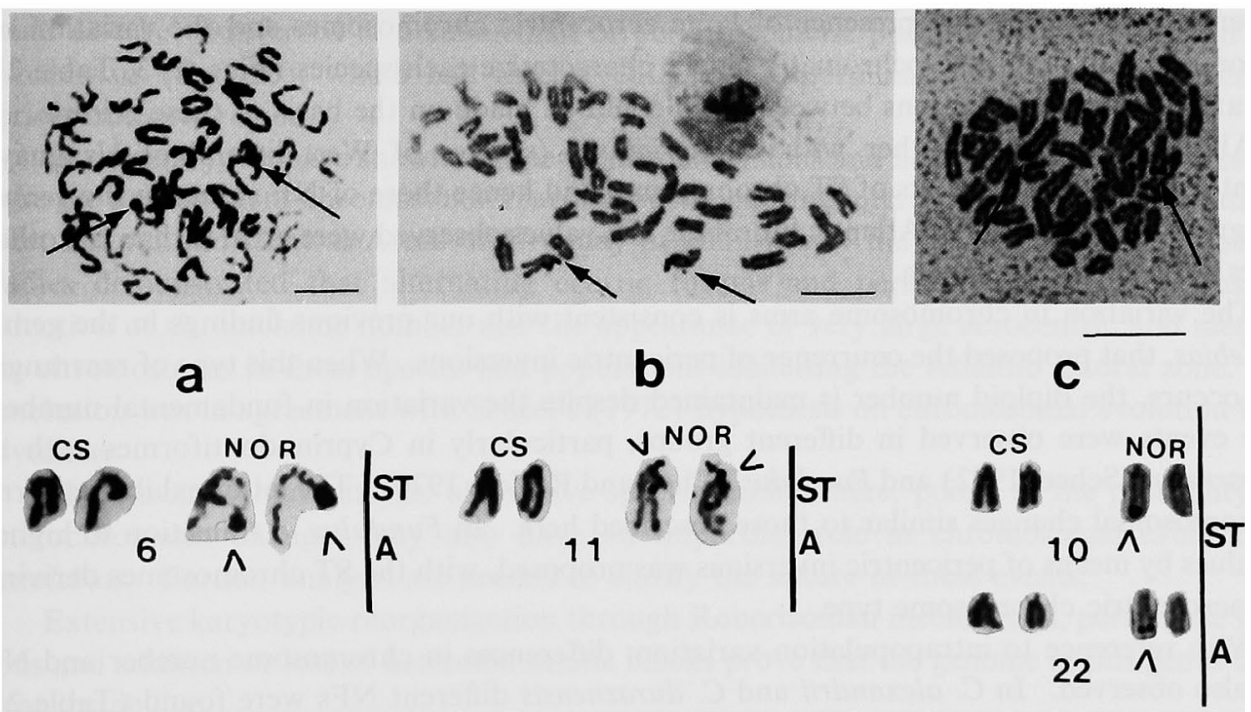

Fig. 4. Ag-NOR bearing chromosomes in three species of Cynolebias. Mitotic nuclei treated with Ag-NOR technique (top); Ag-NOR bearing pairs of chromosomes to the right and the same pair by conventional staining on the left (bottom). Arrows and arrowheads indicate the NOR-bearing chromosomes. Bar $=10 \mu \mathrm{m}$. (a) C. adloffi (male). Pair 6 show the Ag-NORs at terminal position. (b) C. gymnoventris (female). Pair 11 show the Ag-NORs at terminal position. (c) C. alexandrii (male). One chromosome of pair 10 and another of pair 22 show the

Ag-NORs at terminal position. 
chromosomal positions which formed heterochromatic chromocenters in interphase nuclei. These C-heterochomatic blocks evidenced a tendency to adhesion even at mitotic metaphase (Fig. 3b). C. alexandrii and C. gymnoventris had small blocks of constitutive heterochromatin on the three $\mathrm{C}$-band positions.

\section{NOR technique}

Two to four NOR regions were identified on metaphase chromosomes according to each species (Table 2). C. adloffi presents two Ag-NORs at terminal position in pair 6 of ST-A chromosomes (Fig. 4a). In C. affinis 4 NORs were observed, two at terminal position of pair 3 (ST-A chromosomes) while pair 7 bears the Ag-NOR on the short arm which is also observed as C-heterochromatic (Fig. 3a). C. duraznensis presents $3 \mathrm{Ag}-\mathrm{NORs}$, one at terminal position of pair 7 (ST-A chromosome type), and two other at submedian-pericentromeric position of pair 10 (ST-A), also heterochromatic (Fig. 3b) and another in pair 22, both on ST-A chromosomes (Fig. 4c). In C. gymnoventris pair 11 bears the Ag-NOR on the short arm which is heterochromatic (Fig. 4b).

\section{Discussion}

Among 32 recognized species of the genus Cynolebias (Amato 1986) 14 have already been karyologically studied. Although originally they proved to be chromosomally uniform (Sola et al. 1981), Máspoli and García (1988), Garcia et al. (1988), Carcía et al. (1993) demonstrated that specimens beloging to populations from Uruguay presented a high level of chromosome variation. Their diploid chromosome counts range from 34 to 48 and all species with counts lower than 48 have distinctly large biarmed chromosomes.

In spite of the overall karyotype resemblance between the five species reported in this paper, the different morphologies of the biarmed chromosomes, the differential expression of acrocentric short arms, the presence of large acrocentric chromosomes and the variation on position and size of C-heterochromatic blocks characterize each species (Figs. 2, 3, Table 2). Cytotaxonomic differentiations between them could be made on the basis of these criteria.

All these species, together with $C$. nigripinnis (species of West littoral of Uruguay) presented the highest numbers of ST chromosomes and hence those of NF values in the genus. In C. gymnoventris from the Atlantic litoral the NF values observed were greater than the other species studied from this area.

The variation in chromosome arms is consistent with our previous findings in the genus Cynolebias, that proposed the ocurrence of pericentric inversions. When this type of rearrangement occurs, the diploid number is maintained despite the variation in fundamental number. These events were observed in different groups, particularly in Cyprinodontiformes such as Aphyosemion (Scheel 1972) and Fundulus (Chen and Ruddle 1970). The latter exhibit patterns of chromosomal changes similar to those described here. In Fundulus, a transition to higher NF values by means of pericentric inversions was proposed, with the ST chromosomes deriving from acrocentric chromosome type.

With reference to intrapopulation variation, differences in chromosome number and NF were also observed. In $C$. alexandrii and $C$. duraznensis different NFs were found (Table 2). These findings were coincident with the pericentric inversion polymorphisms and polytypies showed by other species of Cynolebias (unpublished data).

The heterochromatin distribution can be used as further proof for the existence of pericentric inversions. Small positive C-bands were observed in pericentromeric and telomeric positions in $C$. adloffi and C. affinis (Fig. 3a, Table 2). The other three species also have interstitial heterochromatic blocks (Fig. 3b, Table 2). 
A hypothetical ancestral karyotype with 48 acrocentric chromosomes would presumably imply the occurrence of centromeric C-bands. These typical positions were well documented in other Cyprinodontiformes by Kornfield (1981) in many species of Fundulus, Uwa and Ojima (1981) in Oryzias. Our present results together with our previous observations (García et al. 1993) prove that the actual banding patterns found in Cynolebias could certainly be the result of pericentric inversions during their karyotypic reorganization.

Nevertheless this confirmation, the differential patterns of $\mathrm{C}$-banding found in these five species (Table 2) led us to suggest the possibility that loss or gain of heterochromatic material (John 1988) should not be ruled out as another viable alternative for karyotypic variability found in this genus. This hypothesis could explain the existence of large heterochromatic blocks, like those detected in $C$. duraznensis which were the most notorious in the genus (Fig. 3b).

Also, the increase of NF and the presence of large acrocentric chromosomes observed in C. duraznensis, $C$. alexandrii and C. gymnoventris (Figs. 1c-e) could be originated by extensive heterochromatic addition as we observed in C. duraznensis (Fig. 2b).

The finding of two accesory micro B chromosomes in a female of C. affinis (Fig. 3a) establish the first report of the ocurrence of supernumerary chromosomes in the genus Cynolebias. The presence of this type of chromosomes is well documented in fishes (Pauls and Bertollo 1983, Bellintani and Moreira-Filho 1992). Very small chromosome fragments consisting of a centromere and minute adjacent segments could arise through various kinds of deletions and translocations (White 1977). However this variation was incompletely characterized due to small sample size, and the lack of a detailed study to determine the stability of their inheritance.

Number and localization of NORs in the five species are also consistent with the precedent findings. Considering the ubiquity of NORs at terminal position in the species of Cynolebias and other Cyprinodontiformes, we can suggest that through the ocurrence of inversions they could also be transferred to a submedian or pericentromeric position. It was observed in $C$. duraznensis (Fig. 3b), which had three NORs, two at terminal position and another in a pericentromeric region.

In summary, we have shown that pericentric inversions and heterochromatic changes seem to be the predominant chromosomal rearrangement, causing inter and intraspecific variation in West Litoral and Central Areas of Uruguay in killifishes of the genus Cynolebias. Previous studies demonstrated that alternating centric fusions and pericentric inversions cause the reduction of chromosome number and the appearance of very large acrocentric and metacentric chromosomes in those species and populations inhabiting the Atlantic Litoral zone. This conclusion was in agreement with Scheel's (1972) hypothesis on chromosomal evolution in the Rivulinae.

The chromosomal analysis of the five species studied here, points to the possibility that heterochromatin changes may also have an importnat role in chromosomal evolution of Cynolebias. Further analysis are needed to clarify the nature of these events.

Extensive karyotypic reorganization through Robertsonian mechanisms, pericentric inversions and addition or loss of heterochromatic blocks prove that the genome in this genus shows great instability.

\section{Summary}

Cytogenetic observations in five species of South American killifishes of the genus Cynolebias reveals chromosome variation at the arm level, but not in diploid number. In this instance pericentric inversions seem to predominate in karyotypic reorganization. Hetero- 
chromatin changes may also play an important role in the chromosomal evolution of this genus as evidenced by the presence of large heterochromatic blocks in some of these species. The high karyotypic heterogeneity observed at inter and intraspecific level, confirms the great genome instability detected in this genus.

\section{Acknowledgements}

The authors are grateful to CSIC (Comisión Sectorial de Investigación Científica) for partial financial support, to the Government of Japan for equipment donation. We would like to thank Drs. Rafael De'Sa, F. Alvarez and Fco. Panzera for reviewing the manuscript. We are grateful to Dr. Luis Malabarba for specimens collection from R. G. Do Sul (Brasil) and to Dr. Rafael Cuadrado for donation of specimens of $C$. affinis.

\section{References}

Amato, L. H. 1986. Seis especies nuevas del género Cynolebias Steindachner, 1876 de Uruguay y Paraguay (Cyprinodontiformes, Rivulidae). Com. Zool. Mus. Montevideo 162: 1-27.

Bellintani, L. and Moreira-Filho, O. 1992. B chromosomes in Astyanax scabripinnis (Pisces, Characidae). Heredity 69: $50-56$

Bertollo, L. A. C., Takahashi, C. S. and Moreira-Filho, O. 1978. Karyotypic studies of two allopatric populations of the genus Hoplias (Pisces, Erythrinidae). Rev. Brasil. Genet. 2: 17-37.

Chen, T. R. and Ruddle, F. H. 1970. A chromosomal study of four species and hybrid of the killifish genus Fundulus (Cyprinodontidae). Chromosoma 29: 255-267.

Denton, T. E. 1973. Fish Chromosome Methodology. C. C. Thomas Ed: Illinois.

Garcia, G., Máspoli, M. C. and Scvortzoff, E. 1988. Estudio citogenético en especies del género Cynolebias Steindachner, 1876 (Cyprinodontiformes, Rivulidae). Res. V Reun. Iberoamericana de Conservación y Zoologia de Vertebrados. Montevideo, Uruguay. pp. 22.

- Scvortzoff, E., Máspoli, M. C. and Vaz-Ferreira, R. 1993. Analysis of karyotypic evolution in natural population of Cynolebias (Pisces: Cyprinodontiformes, Rivulidae) using banding techniques. Cytologia 58: 85-94.

Howell, W. M. and Black, D. A. 1980. Controlled silver staining nucleolus organizer regions with protective colloidal developer: a 1-step method. Experientia 36: 1014-1015.

Kornfield, I. 1981. Distribution of constitutive heterochromatin and the evolution of the sex chromosomes Fundulus. Copeia 4: $916-918$.

John, B. 1988. I. The biology of hetrochromatin. In: Ram S. Verma eds. Heterochromatin. Molecular and Structural Aspects. Cambridge University Press, USA. pp. 1-147.

Levan, A., Fredga, K. and Sandberg, A. A. 1964. Nomenclature for centromeric position on chromosomes. Hereditas 52: 201-220.

Máspoli, M. C. and Garcá, G. 1988. Estudio comparativo del cariotipo de especies del género Cynolebias Steindachner, 1876 (Cyprinodontiformes, Rivulidae) del Uruguay. Bol. Soc. Zool. Uruguay 2a. época 4: 27-33.

Mc Phail, J. D. and Jones, R. L. 1966. A simple technique for obtaining chromosomes from teleost fishes. J. Fish. Res. Board of Canada 23: 767-769.

Parenti, L. 1981. A phylogenetic and biogeographic analysis of Cyprinodontiformes (Teleostei, Atherinomorpha). Bull. Amer. Mus. Nat. Hist. 168: 340-557.

Pauls, E. and Bertollo, L. A. C. 1990. Distribution of a supernumerary chromosome system and aspects of karyotypic evolution in the genus Prochilodus (Pisces, Prochilodontidae). Genetica 81: 117-123.

Scheel, J. 1972. Rivulinae karyotypes and their evolution (Rivulinae, Cyprinodontidae, Pisces). Sonderdruck aus Z. F. Zool. Systematik u Evolutions forschung 10: 108-209.

Sumner, A. T. 1972. A Simple technique for demonstrating centromeric heterochromatin. Exp. Cell Res. 75: 304-306.

Turner, B. J., Grudzien, T. A., Adkisson, K. P. and Worrell, R. A. 1985. Extensive chromosomal divergence within a single River Basin in the Goodeid Fish, Ilyodon furcidens. Evolution 39: 122-134.

Uwa, H. and Ojima, Y. 1981. Detailed and banding karyotype analyses of the Medaka, Oryzias latipes in cultured cells. Proc. Japan Acad. 57: 39-43.

White, M. J. D. 1977. Supernumerary chromosomes. In: Cap. 10, Third ed. Cambridge Univ. Press. Animal Cytology and Evolution. London. pp. 312-333. 